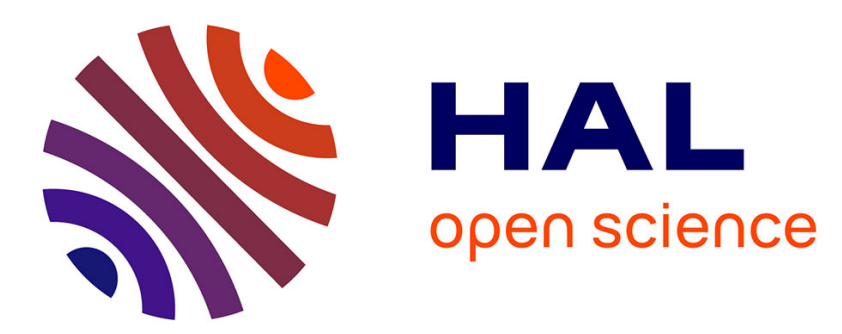

\title{
The planar cell polarity Vangl2 protein: From genetics to cellular and molecular functions
}

Éric Bailly, Alexandra Walton, Jean-Paul Borg

\section{To cite this version:}

Éric Bailly, Alexandra Walton, Jean-Paul Borg. The planar cell polarity Vangl2 protein: From genetics to cellular and molecular functions. Seminars in Cell and Developmental Biology, In press, 10.1016/j.semcdb.2017.10.030 . hal-01785416

\section{HAL Id: hal-01785416 https://hal.science/hal-01785416}

Submitted on 15 May 2018

HAL is a multi-disciplinary open access archive for the deposit and dissemination of scientific research documents, whether they are published or not. The documents may come from teaching and research institutions in France or abroad, or from public or private research centers.
L'archive ouverte pluridisciplinaire HAL, est destinée au dépôt et à la diffusion de documents scientifiques de niveau recherche, publiés ou non, émanant des établissements d'enseignement et de recherche français ou étrangers, des laboratoires publics ou privés. 


\section{Title :}

The Planar Cell Polarity Vang12 protein: from genetics to cellular and molecular functions.

\section{Authors :}

Eric Baillya ${ }^{\mathrm{a}}$ Alexandra Walton ${ }^{\mathrm{a}}$ and Jean-Paul Borga ${ }^{\mathrm{a}}$

a Centre de Recherche en Cancérologie de Marseille (CRCM), 'Cell Polarity, Cell Signalling, and Cancer', Equipe Labellisée Ligue Contre le Cancer, Inserm, U1068, Marseille, F-13009, France, CNRS, UMR7258, Marseille, F-13009, Institut Paoli-Calmettes, Marseille, F-13009, France, Aix-Marseille University, UM 105, F-13284, Marseille, France

${ }^{*}$ Corresponding author*

E-mail addresses : eric.bailly@inserm.fr (E. Bailly) and jean-paul.borg@inserm.fr (J.-P. Borg) 


\begin{abstract}
Planar cell polarity (PCP) refers to the capacity of a tissue, typically, but not exclusively, an epithelium, to transmit directional information across the tissue plane such that its cellular constituents can differentiate, divide or move in a coordinated manner and along a common axis, generally orthogonal to the apical-basal axis. PCP relies on a core module of highly conserved proteins originally identified in Drosophila which can act intra- and extracellularly. In this review, we focuse on the vertebrate ortholog of one of these core PCP components, namely the Vang12 protein. After a brief historical perspective, we discuss novel cellular settings for which a cellular Vang12 requirement has been recently documented, with a particular emphasis on adult tissues that rely on Vangl2 for the maintenance of their regenerative capacity or their physiological functions. Finally we compile the most recent data about Vang12 interacting proteins.
\end{abstract}


Vang12 is a vertebrate counterpart of the Drosophila melanogaster Vang Gogh (Vang)/Strabismus (Stbm) protein, discovered nearly two decades ago by virtue of its central role in planar cell polarity (PCP) $[\mathbf{1 , 2}]$. Pioneering genetic studies conducted in this organism identified a total of six so-called core PCP components, which in addition to Vang/Stbm included two seven-pass transmembrane proteins, Frizzled (Fz) and Flamingo (Fmi)/Starry Night (Stan), and three cytoplasmic factors, Dishevelled (Dsh), Prickle (Pk) and Diego (Dgo) [3]. This set of core PCP proteins appears remarkably well conserved as orthologs can be easily recognized throughout the animal kingdom with very few exceptions $[4,5]$.

Vertebrates possess a second Vang/Stbm ortholog, Vangl1, that is not found in Drosophila or C. elegans. Vangl1 and Vang12 are closely related and exhibit a large number of common interactors. The present review mainly focuses on Vang12 as genetic studies support the view that the two paralogs have to a large extent overlapping functions notably in the context of mouse development [6,7].

Vang12 is a membrane-embedded protein characterized by the presence of four internal and contiguous transmembrane domains in the amino-terminal half (Figure 1a). The protein exhibits no canonical signal peptide and its amino- and carboxy-terminal regions are predicted to be exposed to the cytosol (Figure 1b). This topology is supported by immunofluorescence data obtained with intact, i.e. non-permeabilized cells, showing the nonaccessibility of an epitope tag introduced into the N- or C-terminal regions of Vangll whereas the same tag is readily accessible to antibodies when inserted in the predicted extracellular loops located between the first and second and between the third and fourth transmembrane domains of Vangl1 [8]. Besides the presence of two Ser/Thr phosphorylation clusters in the cytoplasmic N-terminal region of Vang12 [9], the functional contribution of this region remains poorly characterized. This contrasts with the long intracellular C-terminal region which harbors interaction domains for multiple protein partners, including the two PCP components Dvl and Pk [10,11]. A trans Golgi network (TGN) export signal and a conserved PDZ binding motif (PBM) also map to this region [2,12]. It is also in this region that two missense mouse mutations causing a looptail phenotype have been mapped [10].

A salient feature of the core PCP module is the capacity of its components to segregate in a stereotyped and highly asymmetric manner, first along the apical-basal polarity axis and second, but most importantly, in a specified direction of the epithelial sheet [13]. This is best illustrated in the case of the developing Drosophila wing epithelium, an experimental setting that has tremendously contributed to our understanding of planar polarity organization and PCP-mediated regulatory mechanisms [14]. The power of this model stems from the fact that 
morphological manifestations of planar polarity can be directly read out through the stereotyped positioning and orientation of single actin-rich cell appendages, the trichomes that each cell of the wing epithelium assemble at its distal edge (Figure 2a). Trichome assembly along the proximal-distal axis is preceded by a dramatic cellular redistribution of the core PCP proteins from a uniform apicolateral to a highly asymmetric localization along the same axis. During this dynamic process Fz, Dsh and Dgo accumulate at the distal side, while Vang/Stbm and Pk concentrate on the opposite, i.e. proximal region (Figure 2a). This cellular asymmetry is thought to result from an intricate series of antagonistic and stimulatory interactions between the two complexes. The reciprocal inhibitory interactions that operate intracellularly between Fz-Dsh-Dgo and Vang-Pk are intercellularly counterbalanced by stabilizing interactions occurring between the Fmi-Fz complex of one cell and the Fmi-Vang complex of its immediately adjacent neighbor (Figure 2b). Such intercellular interactions serve at least two functions: the bridging of neighboring cells and the propagation of PCP signal from cell to cell [15]. These spatially integrated feedback-loops also account for both the interdependent localization property and the extreme dosage-sensitivity of the whole core PCP module, and explains in particular why loss or overexpression of any of the core components randomize the localization and polarity of the other core proteins. They also provide a molecular basis for how the transmembrane core PCP actors can function both in a non-cell autonomous and cell autonomous manner. It is worth noting here that similar asymmetric localization patterns of core PCP components have been described in planar polarized vertebrate epithelia, from mouse tissues such as cochlear inner ear [16,17], epidermis [11], limb [9] or trachea [19], to Xenopus larval skin [20].

The mechanisms governing the asymmetric distribution of the core PCP factors are progressively being unraveled. Yet a pending question remains regarding the symmetrybreaking cues that orient planar polarity in a particular direction [21]. Earlier studies hypothesized that the global PCP module comprising the protocadherins Fat (Ft) and Dachsous (Ds) and the Golgi-associated Four-jointed (Fj) kinase could play an instructive role in providing the directionality to the core PCP module. This scenario however was ruled out after a genetic analysis performed in Drosophila unambiguously demonstrated that the FtDs module acts in parallel to rather than upstream of the core PCP pathway [22]. Other obvious candidates for external cues directing PCP orientation are the secreted Wnt ligands as PCP and the Wnt-Fz canonical pathways share at least two components: the Fz receptor itself which acts as a Wnt receptor in the canonical Wnt cascade and its direct partner Dsh. Data obtained in the Drosophila wing epithelium [23] and the mouse limb bud [9] lend strong support to this hypothesis $[\mathbf{2 4 , 2 5 ]}$. 
Several vertebrate models have been exploited to study PCP functions, including mouse, Xenopus and zebrafish embryos. Remarkably in all these animal models, loss of Vang12 function is invariably associated with the occurrence of neural tube defects (NTDs), the most severe form of which is the craniorachischisis phenotype with a complete opening of the neural tube from the midbrain-hindbrain boundary up to the tail tip [26]. NTDs result from disrupted convergent-extension (CE) movements that normally take place at the gastrulation and neurulation stage of embryogenesis. Early studies of Vang12 in mammals have benefited from a spontanous Looptail ( $L p)$ mutant mouse line isolated nearly seventy years ago by Strong and Hollander [27], long before the mutation could be mapped to the Vangl2 gene [28]. The $L p$ encoded protein harbors a S464N substitution that confers a semidominant looped tail phenotype to heterozygous mice while $L p / L p$ homozygous embryos die in utero with a craniorachischisis phenotype [27]. The $L p$ allele has been used to document several genetic interactions of Vang12, in particular with the apicobasal polarity protein Scribble [29,30]. Using the planar polarized stereociliary bundles of hair cells in the mouse inner ear as a readout, Montcouquiol et al. could document extensive orientation anormalities, i.e. PCP defects, in the cochlea of $L p$ mouse mutants [26]. Consistent with the $L p$ phenotype in the mouse model, familial or sporadic cases of human NTDs have been reported in the litterature for individuals harboring spontanous heterozygous missense mutations in the VANGL2 locus [31,32].

\section{New PCP-dependent cellular functions of Vangl2}

The recent years have seen the emergence of novel mammalian models addressing Vang12 functions beyond conventional PCP functions (table 1). The mouse developing tooth, for instance, has been shown to require Vangl2 at an early step of its morphogenetic program, when a signaling center has to emerge and organize before instillating its differentiation program to the whole dental epithelium [33]. Another model is provided by the mouse tongue [34]. The dorsal epithelium of this organ is covered by several thousands of papillae whose morphological asymmetry present a degree of local order high enough such that a stereotyped macroscopic pattern of polarization can be deduced, thereby allowing PCP defects to be quantitatively assessed. Using conditional knockout constructs of Vangll and Vangl2 in the tongue epithelium, Wang et al. observed strong papillae orientation defects in the tongue of Vangl1, Vangl2 double mutant mice [34], a phenotype that they found more penetrant than in the context of a $F z 3, F z 6$ double mutation [35]. Whether this new role of Vangl1 and Vangl2 also requires their spatial segregation along the plane of the mouse lingual epithelium has not been addressed yet and will certainly deserve further immunolocalization studies. 
Other mouse adult organs have caught the attention of PCP investigators, with the rationale that Vang12 might contribute repair and homeostatic functions after birth (Table 1). Consistent with this idea, organs such as the brain, lung or kidney have been found to express substantial levels of Vang12 [36]. In the case of adult kidney, induction of Vangl2 expression and of other PCP components has been observed in response to glomerular injury [37]. In this experimental setting, Rocques et al. could provide evidence that podocyte-specific ablation of Vang12 exacerbates glomerular lesions [37], thereby arguing in favor of a protective role of Vang12 in this context. Similar conclusions have been reached with the lung [38]. As for the kidney [39], branching morphogenesis of the lung takes place late in the development and critically depends on Vangl2 [40]. Recent findings indicate that the lungs of adult mice with slightly compromised Vangl2 fonction due to a heterozygous $\operatorname{Vangl} 2^{L p /+}$ genetic background display larger alveolar spaces than wild type lungs, defects that persist as the animals age and are associated with impaired lung functions. Although the possibility that the altered lung function seen in $\operatorname{Vangl}^{\mathrm{Lp} /+}$ adult mice stems from earlier embryonic defects has not been formally excluded, the authors favor the hypothesis that these defects reflect a disrupted regenerative capacity of the angl $^{L p /+}$ lung tissue [38].

Using the mouse cornea as another model to investigate PCP functions, it has been reported that Vang12 is highly expressed in the adult tissue [41]. Furthermore, targeted Vangl2 inactivation strongly impairs in vitro directional migration and alignment properties of corneal epithelial cells [41]. These results have been confirmed by in vivo data demonstrating a dramatic decrease of the characteristic centripetal migration of corneal cells from the periphery to the center of the cornea in the cornea of Vangl2 $\mathrm{KO}$ mice. Because cornea is constantly replenished by cells coming from the limbus periphery, the migratory defects caused by the absence of Vang12 is likely to have adverse repercussions on the regenerative capacity of this tissue. Evidence for a role of Vangl2 in adult tissues has also been obtained in studies of the male and female reproductive systems. In rat testes, Vangl2 expression in Sertoli and germs cells appears to play a critical role in the polarity, maturation and transport of spermatids during spermatogenis [42] while periodic expression of Vangl2 in the mouse uterus has been functionally linked to proper crypt formation and blastocyst implantation and development [43]. The contribution of Vangl2 to the planar polarized ciliary beating in monoand multi-ciliated cells is now well established [44]. While first demonstrated in embryonic contexts, this Vangl2 function has been extended to postnatal events in the brain [45] as well as in the trachea [19]. 
Vang12, like its fly counterpart Vang/Stbm, localizes to the plasma membrane in planar polarized epithelial tissues $[\mathbf{9 , 1 6 , 1 8}$. Our knowledge of the regulatory factors responsible for the trafficking of Vang12 from its site of biosynthesis, i.e. the endoplasmic reticulum (ER) to the place where PCP signaling is supposed to occur, i.e. the cell surface, is slowly progressing. Two genetic studies [46,47] focusing on mouse lines with PCP-related phenotypes have independently isolated mutant alleles of $\operatorname{Sec} 24 \mathrm{~b}$, a gene that encodes a component of the coat protein complex II (COPII) involved in the ER-to-Golgi transport [48]. The finding that $\operatorname{Sec} 24 b$ genetically interacts with the dominant negative Vangl2 looptail mutant provided a first hint that the two genes might function in the same pathway. A role for Sec $24 \mathrm{~b}$ in the vesicular trafficking of Vangl 2 has been demonstrated by elegant biochemical experiments showing that the loading of Vangl2 cargos onto vesicles could be recapitulated in an in vitro reaction assay containing recombinant Sec24b [46]. As expected, targeting of Vang12 to the cell surface is impaired upon genetic inactivation of $\operatorname{Sec} 24 b[\mathbf{4 6 , 4 7 , 4 9 ]}$.

In a search for small GTP-binding proteins that might regulate further downstream events of Vang12 trafficking, Guo et al. [12] could ascribe an important role to the small GTPase Arfrp1 and the clathrin adaptor complex (AP-1) in Vangl2 export from the TransGolgi Network (TGN). Downregulation of either protein was found to induce a similar phenotype characterized by a massive accumulation of Vang12 in a juxtanuclear compartment that colocalized with the TGN marker Golgin 97. This work has also provided evidence for the existence of a basolateral sorting tyrosine-based motif (YYXXF) in the C-terminal cytosolic domain of Vang12 that is absolutely required for the interaction of Vang12 with the $\mu 1$ subunit of AP-1 and for its TGN export. The model proposed by these authors is that the membrane recruitment of AP-1 by Arfrp1 exposes a domain of $\mu 1$ adaptin that allows the interaction and thereby the loading of Vangl2 into transport cargos [12]. The finding that localization of Frizzled 6 and Celsr1, two other components of the mammalian core PCP module, is insensitive to siRNA-mediated silencing of Arfrp1 and the $\mu 1$ adaptin is interesting as it suggests that distinct transmembrane PCP proteins use specific sorting machineries to ensure their polarized delivery to the right site. The TGN sorting mechanism of Vang12 appears evolutionarily conserved as polarized localization of Vang/Stbm in Drosophila requires orthologs of ArfRp1 and AP-1 [50] and because the YYXXF sorting motif identified in Vangl2 is also found in Vang/Stbm [12].

Fluorescence recovery after photobleaching (FRAP) experiments performed in the Drosophila wing model [51] or more recently in the mouse oviduct [52] support the notion that cellular asymmetry of the core PCP proteins is achieved through their rapid turnover at the plasma membrane followed by a progressive stabilization at specialized subdomains or 
punctae [51]. Along the same lines, Vangl2 dynamically redistributes to anterior cell edges at the time mesodermal cells undergo CE movements in zebrafish or Xenopus embryos [53,54]. Yet our current understanding of the molecular mechanisms involved in the dynamic behavior of Vangl2 is still limited. Biochemical evidence for Vangl2 endocytosis has been reported using cell surface biotinylation of ectopically expressed Vangl2 in HEK293T cells [55]. In this assay, a small amount of the overexpressed Vangl2 pool could be detected among the cell surface labeled proteins, a fraction that markedly increased when dominant-negative forms of two well-established endocytic regulators namely Rab5 and dynamin were co-expressed [55]. Other trafficking regulatory factors like GIPC1 and SNX27 are likely to play an active role in Vang12 recycling at the plasma membrane. Both factors harbor a PDZ domain that shows a robust yeast two-hybrid interaction with the PBM of Vangl2 [56,57]. GIPC1, in a complex with the actin motor Myosin IV, has been proposed to regulate the pool of Vangl2 at the plasma membrane, possibly by powering one of its internalization steps [56]. SNX27, on the other hand, is an early endosome-associated retromer component that may promote the retrieval and/or recycling of endocytosed Vangl2 back to the plasma membrane or to the TGN compartment [58]. Other proteins such as Rack1 or Syndecan 4 (Sdc4) have also been postulated to participate in the control of some undefined Vang12 trafficking events based on their physical [59] or genetic interactions [60,61] with Vangl2. Vang12 and Sdc4 both contain a C-terminal PBM, but whether this motif is required for their interaction, for instance via a third unidentified partner with multiple PDZ domains remains to be addressed.

\section{Molecular organization and partners of Vangl2}

Over the past 15 years, many Vangl2 interactors have been isolated through a variety of methods (see table 2). While Vangl2 interacting proteins like Scribble [16,57,62], GIPC1 [56,57], Ror2 [9], p62/SQSTM1 [63], AP-1 [12], MCC [64] or more recently Nrdp1 [65] have been validated by independent functional studies, others need to be further characterized. Nevertheless the list of Vangl2 interacting proteins provided in Table 2 already gives us an idea of the large spectrum of regulatory mechanisms exploited or contributed by Vangl2 under normal or pathological conditions.

Not surprisingly, and excluding Vangl2 itself and Vangl1, four Vangl2 interacting proteins, namely Dvl $[\mathbf{1 0 , 6 6}]$, Fz3 [16], Pk1 [11,67] and the vertebrate Fmi homolog Celsr1 [18] are core PCP components whose fly orthologs also assemble in large complexes with Vang/Stbm [14]. These interactions are therefore likely reflecting ancestral binding properties of the core PCP components. We and others have provided biochemical evidence that Vang12 can self-interact and also form hetero-oligomers with Vangl1 [36,68]. Moreover, we could 
demonstrate that Vang11-Vang12 hetero-oligomers required neither the N-terminal nor the Cterminal cytoplasmic domains of Vangl2, as a fragment of Vangl2 encompassing its four transmembrane domains still coimmunoprecipitated with Vangl1 [36]. The ability of Vangl1 and Vang12 to hetero and homo-oligomerize echoes the supramolecular organization of fly core PCP complexes into signalosome-like structures as recently reported [69]. It is currently unclear whether Vangl1 and/or Vangl2 are endowed with paralog-specific functions or structural properties, but if this turned to be the case and as depicted in Figure 3, the composition, stochiometry and relative abundance of such oligomers could have important functional implications.

The conserved PDZ interaction that Scribble entertains with Vang/Stbm/Vangl proteins $\mathbf{1 6 , 6 2 , 7 0 ]}$, although still poorly understood from a mechanistic point of view, is nevertheless thought to be functionally important [36]. Considering the pivotal role of Scribble in the maintenance of apico-basal organization in polarized epithelia [62], this scaffold protein appears ideally positioned to serve as a molecular link between apico-basal polarity regulators and PCP factors (Figure 3) as proposed by a recent study [71]. Scribble, however, is not the only PDZ protein to bind the PBM of Vangl2 and at least six other PDZ proteins have been shown to do so as well. These include GIPC1 [56] and SNX27 [57] whose possible function in Vangl2 trafficking has been discussed above. The multi-PDZ domain MAGI-3 protein has been proposed to bridge Frizzled4 and Vangl2 to promote Rac1dependent activation of JNK signaling [72]. DLG/SAP97 and PSD95, on the other hand, are two members of the MAGUK protein family that bind the PBM of Vang12 in very diverse cellular contexts $[\mathbf{5 7 , 7 3 , 7 2 ]}$. These adaptor proteins are widely used by cell surface receptors, notably in neuronal cells, for their targeting to specialized membrane domains. Vangl2 indeed functions in neuronal cells and in particular in the postsynaptic compartment where it is found to be strongly enriched. A recent study indicates that the PDZ interaction between Vang12 and the postsynaptic protein PDS95 is not absolutely required for the synapse-associated distribution of Vangl2 and suggests that at that site Vangl2 might serve to control the clustering of postsynaptic molecules [75]. The last PDZ protein to robustly interact with the PBM of Vangl2 is PDZRN3 [57]. However, whether this E3 ubiquitin ligase targets Vang12 for polyubiquitination in a PBM-dependent manner is currently unknown but will certainly warrant further investigations.

Among the other Vang12 interactors, Ror2, stands out as this single transmembrane receptor tyrosine kinase is strongly suspected to translate a mouse Wnt5a proximo-distal (PD) gradient into a global directional cue through a graded phosphorylation of Vangl2 that promotes its own asymmetric localization [9]. Ryk, another RTK member with a 
nonfunctional kinase domain seems to operate through a very similar mechanism [76]. MCC is a PDZ protein that binds Vangl2 in a manner similar to Dvl, i.e. through the same unconventional internal PDZ binding motif of Vang12 and functional data support a role of MCC in the Wnt5a-mediated PCP pathway, with MCC acting downstream of Ror2 and Ryk and upstream of RhoA/JNK [64]. Potentially acting in the same signaling pathway, Dact1 [77] and Sestd1 [78], have also been shown to interact with Vang12. Although the mechanism is not entirely clear, it has been proposed that Dact1 and SestD1 act in a complex downstream of Vangl2 to activate a Rho GTPase branch of the PCP signaling pathway. Interestingly, Vangl2 has also been reported to directly bind Rac1 and RhoA [79]. In vitro as well as in vivo functional data from the same study led the authors to propose that this might allow Vang12 to recruit active Rac1 to adherens junctions where the Rho GTPase would affects cell adhesion and the actin cytoskeleton. E-Cadherin is a major component of AJs, in epithelial cells and Vang12 expression has been shown to control its internalization in different cellular contexts [55]. Among the many functions of Vang12, internalization clearly appears as a recurrent theme as this PCP component has been found to interact with and enhance the endocytosis of an ever growing list of PCP and non-PCP proteins, including Frizzled 3 [80], the E- and NCadherin AJ components [55,81], the podocyte protein nephrin [82] or the matrix metalloproteinase MMP14 [83].

A newcomer to the list of Vang12 interactors is the p62/SQSTM1 autophagy receptor [63] that has been recently co-purified with VANGL2 upon immunoprecipitation with a highly specific monoclonal antibody [55]. A previously uncharacterized small region (aminoacid 346-388) in p62/SQSTM1 was shown to be necessary and sufficient for the interaction with the cytoplasmic C-terminal region of VANGL2. The usual autophagy partners of p62/SQSTM1such as LC3 were undetectable in the immunopurified fraction, indicating that the VANGL2-p62/SQSTM1 complex had no functional relationship with an autophagic process. In this study we propose that this complex constitutes a platform for the recruitment and activation of JNK, an established PCP effector. Importantly, blocking the formation of this complex with a dominant negative p62/SQSTM1 peptide strongly reduced the tumorigenic potential of human breast cancer cells engrafted in the mouse fat pad. Remarkably, the magnitude of the VANGL2-p62/SQSTM1 interaction exhibited an inverse correlation with the occurrence of cell jonctions, strongly suggesting that JNK activation by the Vang12-p62/SQSTM1 platform is strongly enhanced following polarity loss events as frequently observed during tumorigenesis (Figure 4).

Nrdp1, a RING-finger E3 ubiquitin ligase frequently downregulated in aggressive forms of glioblastomas, has been recently shown to physically interact with Vangll and 
Vang12 possibly through a coiled coil interaction with these two paralogs [65]. Published biochemical data also revealed that Nrdp1 does not promote polyubiquitination of Vangl1 and Vang12, despite the fact that it can bind the two proteins. Instead, this E3 ligase was found to stimulate the polyubiquitination of Dvl in a Vangl-dependent manner and through K63ubiquitin linkages [65].The model proposed by the authors posits that Vang11/2-stimulated and Nrdp1-dependent polyubiquitination of Dvl1 prevents Dvl binding to phosphatidic acid and consequently the plasma membrane recruitment of Dvl1, thereby blocking the signals lying downstream of Dvl. Nrdpl therefore behaves as a negative regulator of PCP transduction. While, as already mentioned, Vangl2 does not seem to be a substrate for this E3 ligase, it will be interesting to investigate whether this enzyme targets other regulatory proteins in a similar, i.e.Vangl2-dependent manner.

\section{Concluding remarks}

Vang/Stbm and its vertebrate counterparts, Vangl1 and Vang12 have, over the years, caught the attention of more and more laboratories. Arguably, our current understanding of these key PCP molecules has greatly improved $[\mathbf{8 4 , 8 5}]$ and will hopefully continue to do so. For instance, it is now very clear that, contrary to the initial general belief, the PCP functions fulfilled by these two paralogs are not limited to embryonic developmental morphogenetic event but are frequently maintained and exploited thoughout or over a long period of the adult life $[38,41,43,38,52,86]$. Other recent major advances in our conceptual understanding of PCP establishment mechanisms have come from the elucidation of a global cue used by some tissues to coordinately elongate in a proximo-distal direction $[\mathbf{2 4 , 2 5}]$ or from the recent use of sophisticated quantitative imaging techniques to address the fundamental question regarding the composition of the core protein complex in vivo [69].

Yet, we still have a lot to learn. For instance, we all would like to know more about how Vangl1/2 proteins reach their final destination, are targeted for internalization recycling or destruction, whether they also make higher-order assemblies, where and with whom. Another long standing and still unresolved issue relates to their status: should we really conceive them as bona fide membrane receptors for secreted ligands, and if not, what other proteins could do the job? While Ror2 has already been proposed to serve such a role [9], the list is likely to grow in the next decade. A new question then immediately comes to mind: how many complexes are these two paralogs able to form at the cell surface and/or in intracellular compartments and with which stochiometry? Finally, as their role in tumorigenesis is getting clearer $[\mathbf{6 3}, \mathbf{6 5}, \mathbf{8 7}, \mathbf{8 8}]$ could these PCP molecules be of any help for 
diagnosis or therapeutic purpose? With all these questions, we have no doubt that many discoveries, and maybe also some surprises, are ahead of us. 


\section{Acknowledgements}

We would like to sincerely apologize to our colleagues whose contributions were not cited in this review due to manuscript length limitation. JP Borg's lab is funded by La Ligue Nationale Contre le Cancer (Label Ligue J.P.B.), Institut Paoli-Calmettes, Assistance Publique - Hôpitaux de Marseille (fellowship to A.W.), and SIRIC (INCa-DGOS-Inserm 6038). JPB is a scholar of Institut Universitaire de France. 


\begin{tabular}{|c|c|c|c|c|}
\hline $\begin{array}{c}\text { Organ } \\
\text { (species) }\end{array}$ & Vangl2 mutation & Phenotype & $\begin{array}{c}\text { Molecular/ } \\
\text { cellular } \\
\text { Pathway } \\
\end{array}$ & References \\
\hline $\begin{array}{l}\text { Tooth } \\
\text { (mouse) }\end{array}$ & RNA interference & $\begin{array}{l}\text { Retarded tooth } \\
\text { germ growth }\end{array}$ & ND & [33] \\
\hline $\begin{array}{l}\text { Tongue } \\
\text { (mouse) }\end{array}$ & $\begin{array}{c}\text { Vangl2CKO/- } \\
\text {;K14-Cre } \\
\text { (viable) }\end{array}$ & $\begin{array}{c}\text { papillae orientation } \\
\text { defects }\end{array}$ & ND & [34] \\
\hline $\begin{array}{l}\text { Kidney } \\
\text { (mouse) }\end{array}$ & $\begin{array}{c}\text { Vangl2 } 2^{L p / L p} \\
\text { (embryonic lethal) } \\
\\
\text { Vangl2Ex4/Flox } \\
; \text { Pod-Cre } \\
\text { (Podocyte-targeted } \\
\text { Vangl2 KO) } \\
\text { (viable) }\end{array}$ & $\begin{array}{c}\text { Reduced kidney } \\
\text { size, branching and } \\
\text { glomerular } \\
\text { maturation } \\
\text { Normal size } \\
\text { Glomerular } \\
\text { maturation delay } \\
\text { Reduced Podocyte } \\
\text { recovery after } \\
\text { injury }\end{array}$ & $\begin{array}{l}\text { ND } \\
\text { ND }\end{array}$ & $\begin{array}{l}39] \\
{[37]}\end{array}$ \\
\hline $\begin{array}{c}\text { Lung } \\
\text { (mouse) }\end{array}$ & $\begin{array}{c}\text { Vangl } 2^{L p / L p} \\
\text { (embryonic lethal) } \\
\text { Vangl }^{L p /+}\end{array}$ & $\begin{array}{c}\text { Branching defects } \\
\text { Alveolar } \\
\text { enlargement } \\
\text { Imparired adult } \\
\text { lung function } \\
\end{array}$ & $\begin{array}{l}\text { ND } \\
\text { ND }\end{array}$ & $\begin{array}{l}{[40]} \\
{[38]}\end{array}$ \\
\hline $\begin{array}{l}\text { Cornea } \\
\text { (mouse) }\end{array}$ & $\begin{array}{l}\text { Vangl2 }{ }^{\text {Flox } / \text { Flox }} ; \text { Le- } \\
\text { Cre } \\
\text { (Cornea-targeted } \\
\text { Vangl2 KO) }\end{array}$ & $\begin{array}{l}\text { Centripetal cell } \\
\text { migration defects }\end{array}$ & JNK pathway & {$[41]$} \\
\hline $\begin{array}{l}\text { Uterus } \\
\text { (mouse) }\end{array}$ & $\begin{array}{c}\text { Vangl2Flox/Flox; Prg- } \\
\text { Cre }\end{array}$ & $\begin{array}{c}\text { Misdirected } \\
\text { epithelial } \\
\text { evaginations } \\
\text { Defective crypt } \\
\text { formation and } \\
\text { blastocyst } \\
\text { implantation } \\
\end{array}$ & $\begin{array}{c}\text { Wnt5a-R0R1/2 } \\
\text { pathway }\end{array}$ & [43] \\
\hline $\begin{array}{l}\text { Testis } \\
\text { (rat) }\end{array}$ & RNA interferrence & $\begin{array}{c}15 \text { disrupted } \\
\text { spermatid } \\
\text { transport and } \\
\text { polarity }\end{array}$ & $\begin{array}{c}\text { Actin } \\
\text { microfilament } \\
\text { polarization }\end{array}$ & [42] \\
\hline
\end{tabular}




\begin{tabular}{|c|c|c|c|c|}
\hline $\begin{array}{c}\text { Skin } \\
\text { (mouse) }\end{array}$ & Vangl $2^{L p / L p}$ & $\begin{array}{l}\text { Mis-angled hair } \\
\text { follicles }\end{array}$ & $\begin{array}{c}\text { Celsr1 } \\
\text { dependent } \\
\text { asymmetric } \\
\text { localization }\end{array}$ & [18] \\
\hline $\begin{array}{c}\text { Brain } \\
\text { (mouse) }\end{array}$ & $\begin{array}{c}\text { Vangl } 2^{L p / L p} \\
\text { (embryonic lethal) }\end{array}$ & $\begin{array}{c}\text { Ciliary orientation } \\
\text { and alignment } \\
\text { defects }\end{array}$ & - & [45] \\
\hline $\begin{array}{l}\text { Trachea } \\
\text { (mouse) }\end{array}$ & Vangl $2^{L p / L p}$ & $\begin{array}{l}\text { Misoriented motile } \\
\text { cilia in multiciated } \\
\text { tracheal cells }\end{array}$ & $\begin{array}{c}\text { Planar } \\
\text { polarization of } \\
\text { MT-associated } \\
\text { basal bodies } \\
\end{array}$ & [19] \\
\hline
\end{tabular}

Table 1: Vangl2-associated mutant phenotypes beyond conventional PCP functions

Abbreviations used throughout the table:

ND: Not Determined 


\begin{tabular}{|c|c|c|c|c|c|}
\hline $\begin{array}{l}\text { Vangl2 } \\
\text { Partners }\end{array}$ & Method(s) & $\begin{array}{c}\text { Interacting part } \\
\text { of Vangl2 }\end{array}$ & $\begin{array}{c}\text { Vangl1 } \\
\text { Interaction }\end{array}$ & Functional relevance & references \\
\hline $\begin{array}{l}\text { Dvl1, Dvl2 et } \\
\text { Dvl3 }\end{array}$ & $\begin{array}{c}\text { Y2H } \\
\text { GST pull- } \\
\text { down } \\
\text { co-IP }\end{array}$ & $\begin{array}{l}\text { unconventional } \\
\text { internal PBM } \\
\text { requiring } \\
\text { Ser464 }\end{array}$ & Yes & $\begin{array}{l}\text { Proper signaling during } \\
\text { neural tube closure }\end{array}$ & $\begin{array}{l}{[10]} \\
{[66]}\end{array}$ \\
\hline Prickle & $\begin{array}{c}\text { Y2H } \\
\text { GST pull- } \\
\text { down } \\
\text { Affinity } \\
\text { purification/ } \\
\text { MS } \\
\end{array}$ & $\begin{array}{c}\text { Internal C- } \\
\text { terminal domai } \\
\text { n (85 amino } \\
\text { acids })\end{array}$ & Yes & $\begin{array}{c}\text { Fz/Dsh localization } \\
\text { inhibition } \\
\text { Membrane Vangl2 } \\
\text { localization }\end{array}$ & $\begin{array}{l}{[11]} \\
{[67]}\end{array}$ \\
\hline Celsr1/Fmi & Co-IP & ND & Yes & $\begin{array}{l}\text { Interdependent asymmetric } \\
\text { localization }\end{array}$ & [18] \\
\hline Frizzled 3 & co-IP & ND & ND & ND & [16] \\
\hline Scribble & $\begin{array}{c}\text { Y2H } \\
\text { Peptide pull } \\
\text { down } \\
\text { Co-IP } \\
\end{array}$ & C-terminal PBM & Yes & $\begin{array}{l}\text { Vangl2 promigratory } \\
\text { activity. }\end{array}$ & $\begin{array}{l}{[16]} \\
{[57]} \\
{[62]}\end{array}$ \\
\hline MAGI-3 & $\begin{array}{l}\text { pull-down } \\
\text { Co-IP }\end{array}$ & C-terminal PBM & ND* & JNK signaling cascade. & {$[72]$} \\
\hline GIPC1 & $\begin{array}{c}\mathrm{Y} 2 \mathrm{H} \\
\text { co-IP }\end{array}$ & C-terminal PBM & ND* & Regulates Vangl2 trafficking & $\begin{array}{l}{[56]} \\
{[57]}\end{array}$ \\
\hline SNX27 & $\begin{array}{c}\mathrm{Y} 2 \mathrm{H} \\
\text { Co-IP } \\
\end{array}$ & C-terminal PBM & $\mathrm{ND}^{*}$ & ND & $\begin{array}{l}57] \\
{[58]}\end{array}$ \\
\hline PDZNR3 & $\mathrm{Y} 2 \mathrm{H}$ & C-terminal PBM & ND* & ND & {$[57]$} \\
\hline DLG & $\mathrm{Y} 2 \mathrm{H}$ & C-terminal PBM & ND* & $\begin{array}{c}\text { plasma membrane } \\
\text { formation during } \\
\text { cellularization }\end{array}$ & [73] \\
\hline PSD-95 & co-IP & C-terminal PBM & $\mathrm{ND}^{*}$ & $\begin{array}{c}\text { postsynaptic Vangl2 } \\
\text { localization }\end{array}$ & {$[74]$} \\
\hline MCC & co-IP & $\begin{array}{l}\text { C-terminal } \\
\text { region }\end{array}$ & ND & Convergent extension & {$[64]$} \\
\hline VANGL1 & $\begin{array}{l}\text { Affinity- } \\
\text { purification/ } \\
\text { MS } \\
\text { Co-IP }\end{array}$ & $\begin{array}{c}\text { region } \\
\text { encompassing } \\
\text { the four TM } \\
\text { domains }\end{array}$ & Yes & ND & $\begin{array}{l}{[36]} \\
{[68]}\end{array}$ \\
\hline VANGL2 & Co-IP & ND & Yes & ND & $\begin{array}{l}{[36]} \\
{[68]}\end{array}$ \\
\hline p62/SQSTM1 & $\begin{array}{l}\text { Affinity } \\
\text { purification/ } \\
\text { MS }\end{array}$ & $\begin{array}{l}\text { C-terminal } \\
\text { region }\end{array}$ & No & $\begin{array}{l}\text { JNK-dependent cancer cell } \\
\text { proliferation }\end{array}$ & [63] \\
\hline
\end{tabular}




\begin{tabular}{|c|c|c|c|c|c|}
\hline $\begin{array}{l}\text { Vangl2 } \\
\text { Partners }\end{array}$ & Method(s) & $\begin{array}{c}\text { Interacting part } \\
\text { of Vangl2 }\end{array}$ & $\begin{array}{c}\text { Vangl1 } \\
\text { Interaction }\end{array}$ & Functional relevance & references \\
\hline Ryk & $\begin{array}{c}\text { Genetic } \\
\text { interaction } \\
\text { co-IP } \\
\end{array}$ & ND & ND & Increased Vangl2 stability & [76] \\
\hline ROR2 & $\begin{array}{l}\text { Co-IP in } \\
\text { Wnt5a } \\
\text { stimulated } \\
\text { cells. }\end{array}$ & ND & ND & $\begin{array}{l}\text { WNT5A-ROR2 dependent } \\
\text { stimulation of VANGL2 } \\
\text { phosphorylatin }\end{array}$ & [9] \\
\hline Bbs8 & co-IP & ND & ND & $\begin{array}{c}\text { Vangl2 } \\
\text { localization }\end{array}$ & [89] \\
\hline Ift20 & co-IP & ND & ND & $\begin{array}{c}\text { Vangl2 } \\
\text { localization }\end{array}$ & [89] \\
\hline E-Cadherin & Co-IP & $\begin{array}{l}\text { C-terminal } \\
\text { region }\end{array}$ & ND & E-Cadherin internalization & {$[55]$} \\
\hline $\mathrm{N}$-Cadherin & Co-IP & $\begin{array}{l}\text { C-terminal } \\
\text { region }\end{array}$ & ND & $\begin{array}{l}\mathrm{N}-\text { Cadherin internalization } \\
\text { and synapse formation }\end{array}$ & [81] \\
\hline $\begin{array}{c}\text { AP-1 } \\
(\mu 1 \text { subunit })\end{array}$ & $\begin{array}{l}\text { Y2H GST } \\
\text { pull-down }\end{array}$ & $\begin{array}{l}\text { YYXXF sorting } \\
\text { signal (C-ter } \\
\text { region) }\end{array}$ & ND & TGN export of Vangl2 & [12] \\
\hline Rac1 & Co-IP & PBM-dependent & ND & $\begin{array}{l}\text { adherens junctions } \\
\text { formation }\end{array}$ & [79] \\
\hline RhoA & Co-IP & ND & ND & $\begin{array}{l}\text { adherens junctions } \\
\text { formation }\end{array}$ & [79] \\
\hline Dact1 & $\begin{array}{l}\text { Co-IP } \\
\text { pulldown } \\
\text { assays } \\
\end{array}$ & ND & ND & $\begin{array}{l}\text { Morphogenetic events at } \\
\text { primitive streak }\end{array}$ & [77] \\
\hline SestD1 & Co-IP & ND & ND & Unknown & [78] \\
\hline Rack1 & Y2H co-IP & ND & ND & $\begin{array}{l}\text { Vangl2 membrane } \\
\text { localization }\end{array}$ & [59] \\
\hline Nrdp1 & Co-IP & $\begin{array}{l}\text { C-terminal } \\
\text { region }\end{array}$ & Yes & Dvl Ubiquitination & {$[65]$} \\
\hline
\end{tabular}

Table 1: A list of VANGL2 interacting proteins.

Abbreviations used throughout the table

PBM: PDZ Binding Motif

ND: Not Determined

PBM: PDZ Binding Motif

TM: Transmembrane domain

ND*: Not Determined but expected based on highly conserved PBM of Vangl1 and Vang12 


\section{References}

[1] J. Taylor, Abramova N., Charlton J., P.N. Adler. Van Gogh : a new Drosophila tissue polarity gene, Genetics 150 (1998) 199-210.

[2] T. Wolf, G.M. Rubin. Strabismus, a novel gene that regulates tissue polarity and cell fate decisions in Drosophila. Development 125 (1998) 1149-1159.

[3] J.A. Zallen. Planar polarity and tissue morphogenesis, Cell 129 (2007) 1051-1063.

[4] Q. Schenkelaars, L. Fierro-Constain, E. Renard, C. Borchiellini. Retracing the path of planar cell polarity, BMC Evol Biol 16 (2016) 69-81.

[5] R. Hale, D. Strutt. Conservation of planar pathway function across the animal kingdom. Annu Rev Genet 49 (2015) 529-551.

[6] E. Torban, A.-M. Patenaude, S. Leclerc, S. Rakowiecki, S. Gauthier, G. Andelfinger, D.J. Epstein, P. Gros. Genetic interaction between members of the Vangl family causes neural tube defects in mice. Proc Natl Acad Sci USA 105 (2008) 3449-3454

[7] H. Song, J. Hu, W. Chen, G. Elliott, P. Andre, B. Gao, Y. Yang. Planar cell polarity breaks bilateral symmetry by controlling ciliary positioning. Nature 466 (2010) 378-382.

[8] A. Iliescu, M. Gravel, C. Horth, S. Apuzzo, P. Gros. Transmembrane topology of mammalian planar cell polarity protein Vangl1. Biochemistry 50 (2010) 2274-2282.

[9] B. Gao, H. Song, K. Bishop, G. Elliot, L. Garrett, M.A. English, P. Andre, J. Robinson, R. Sood, Y. Minami, A.N. Economides, Y. Yang, Wnt signaling gradients establish planar cell polarity by inducing Vangl2 phosphorylation through Ror2, Dev Cell 20 (2011) 163-176.

[10] E. Torban, H.J. Wang, N. Groulx, P. Gros, Independent mutations in mouse Vangl2 that cause neural tube defects in looptail mice impair interaction with members of the Dishevelled family, J Biol Chem 279 (2004) 52703-52713.

[11] A. Jenny, R.S. Darken, P.A. Wilson, M. Mlodzik, Prickle and Strabismus form a functional complex to generate a correct axis during planar cell polarity signaling, EMBO J 22 (2003) 4409-4420.

[12] Y. Guo, G. Zanetti, R. Schekman, A novel GTP-binding protein-adaptor protein complex responsible for export of Vangl2 from the trans Golgi network, Elife 2 (2013) e00160.

[13] D. Devenport. The cell biology of planar cell polarity, J Cell Biol 207 (2014) 171-179.

[14] P.N. Adler.The frizzled/Stan pathway and planar cell polarity in the Drosophila wing, Curr Top Dev Biol 101 (2012) 1-31.

[15] H. Strutt, D Strutt. Asymmetric localisation of planar polarity proteins : Mechanisms and consequences. Semin Cell Dev Biol 20 (2009) 957-963.

[16] M. Montcouquiol, N. Sans, D. Huss, J. Kach, J.D. Dickman, A. Forge, R.A. Rachel, N.G. Copeland, N.A. Jenkins, D. Bogani, J. Murdoch, M.E. Warchol, R.J. Wenthold, M.W. Kelley, 
Asymmetric localization of Vang12 and Fz3 indicate novel mechanisms for planar cell polarity in mammals, J Neurosci 26 (2006) 5265-5275.

[17] Y. Wang, N. Guo, J. Nathans. The Role of Frizzled3 and Frizzled6 in Neural Tube Closure and in the Planar Polarity of Inner-Ear Sensory Hair Cells. J Neurosci, 26 (2006) 2147-2156.

[18] D. Devenport, E. Fuchs. Planar polarization in embryonic epidermis orchestrates global asymmetric morphogenesis of hair follicles. Nat Cell Biol 10 (2008) 1257-1268.

[19] E.K. Vladar, R.D. Bayly, A.M. Sangoram, M.P. Scott, J.D. Axelrod. Microtubules Enable the Planar Cell Polarity of Airway Cilia, Curr Biol 22 (2012) 2203-2212.

[20] M.T. Butler, J.B. Wallingford. Control of vertebrate core planar cell polarity protein localization and dynamics by Prickle 2. Development 142 (2015) 3429-3439.

[21] J. Wu, M. Mlodzik. A quest for the mechanism regulating global planar cell polarity of tissues. Trends Cell Biol 19 (2009) 295-305.

[22] J. Casal, P.A. Laurence, G. Struhl. Two separate molecular systems, Dachsous/Fat and Starry Night/Frizzled, act independently to confer planar cell polarity, Development 133 (2006), 4561-4572.

[23] Wu J, Roman AC, Carvajal-Gonzalez JM, Mlodzik M. Wg and Wnt4 provide long-range directional input to planar cell polarity orientation in Drosophila. Nat Cell Biol 15 (2013) 1045-1055.

[24] Y. Yang, M. Mlodzik. Wnt-Frizzled/planar cell polarity signaling: cellular orientation by facing the wind (Wnt). Annu Rev Cell Dev Biol 31 (2015) 623-646

[25] B. Gao. Wnt regulation of planar cell polarity (PCP). Curr Top Dev Biol, 101 (2012) 263-295.

[26] E. Torban, C. Kor, P. Gros. Van Gogh-like2 (Strabismus) and its role in planar cell polarity and convergent extension in vertebrates. Trends Genet 20 (2004) 570-577.

[27] L.C. Strong, F. Hollander. Hereditary Loop-tail in the house mouse : Accompanied by imperforate vagina and with lethal craniorachisschisis when homozygous. J Hered, 40 (1949) 329-334.

[28] Z. Kibar, K.J. Vogan, N. Groux, M.J. Justice, D.A. Underhill, P. Gros. Ltap, a mammalian homolog of Drosophila Strabismus/Vang Gogh, is altered in the mouse neural tube mutant Loop-tail. Nat. Genet. 28 (2001) 251-255.

[29] M. Montcouquiol, R.A. Rachel, P.J. Lanford, N.G. Copeland, N.A. Jenkins, M.W. Kelley. Identification of Vangl2 and Scrb1 as planar polarity genes in mammals. Nature 423 (2003) 173-177.

[30] J.N. Murdoch, D.J. Henderson, K. Doudney, C. Gaston-Massuet, H.M. Phillips, C. Paternotte, R. Arkell, P. Stanier, A.J. Copp. Disruption of scribble (Scrb1) causes severe neural tube defects in the circletail mouse, Hum Mol Genet 112 (2003) 87-98. 
[31] Lei YP, Zhang T, Li H, Wu BL, Jin L, Wang HY. VANGL2 Mutations in Human Cranial Neural-Tube Defects. N Engl J Med 362 (2010) 2232-2235

[32] A. Iliescu, M. Gravel, C. Horth, P. Gros. Independent Mutations at Arg181 and Arg274 of Vangl Proteins That Are Associated with Neural Tube Defects in Humans Decrease Protein Stability and Impair Membrane Targeting. Biochemistry. 53 (2014) 5356-5364.

[33] Z. Wu, D . Epasinghe, Jinquan He, Liwen Li, David W. Green, Min-Jung Lee, Han-Sung Jung Altered tooth morphogenesis after silencing the planar cell polarity core component, Vang12, Cell Tissue Res 366 (2016) 617-621.

[34] Y. Wang, J. Williams, A. Rattner, S. Wu, A.G. Bassuk, A. M. Goffinet, J. Nathans. Patterning of papillae on the mouse tongue: A system for the quantitative assessment of planar cell polarity signaling. Dev Biol 419 (2016) 298-310.

[35] Z.L. Hua, H. Chang, Y. Wang, P.M. Smallwood, J. Nathans. Partial interchangeability of Fz3 and Fz6 in tissue polarity signaling for epithelial orientation and axon growth and guidance. Development 141 (2014) 3944-3954.

[36] E. Belotti, T.M. Puvirajesinghe, S. Audebert, E. Baudelet, L. Camoin, M. Pierres, L. Lasvaux, G. Ferracci, M. Montcouquiol, J.P. Borg, Molecular characterisation of endogenous Vang12/Vang11 heteromeric protein complexes, PLoS One 7(9) (2012) e46213.

[37] B.L. Rocque, S. Babayeva, J. Li, V. Leung, L. Nezvitsky, A.V. Cybulsky, P. Gros. Torban E. Deficiency of the planar cell polarity protein Vangl2 in podocytes affects glomerular morphogenesis and increases susceptibility to injury. J Am Soc Nephrol 26 (2015) 576-586.

[38] T. Poobalasingam, L.L. Yates, S.A. Walker, M. Pereira, N.Y. Gross, A.A. M. KolatsiJoannou, M.-R. Jarvelin, J. Pekkanen, E. Papakrivopoulou, D.A. Long, M. Griffiths, D. Wagner, M. Königshoff, M. Hind, C. Minelli, C.M. Lloyd, C.H. Dean. Heterozygous Vang12Looptail mice reveal novel roles for the planar cell polarity pathway in adult lung homeostasis and repair, Mod Mech 10 (2017) 409-423.

[39] L.L. Yates, J. Papakrivopoulou, D.A. Long, P. Goggolidou, J.O. Connolly, A.S. Woolf, C.H. Dea. The planar cell polarity gene Vangl2 is required for mammalian kidney-branching morphogenesis and glomerular maturation. Hum Mol Genet 19 (2010) 4663-4676.

[40] L.L. Yates, C Schnatwinkel, J.N. Murdoch, D. Bogani, C.J. Formstone, S. Townsend, A. Greenfield, L.A Niswander, C.H. Dean. The PCP genes Celsr1 and Vangl2 are required for normal lung Branching morphogenesis. Hum. Mol. Genet. 11 (2010) 2251-2267.

[41] A. S. Findlay, D.A. Panzica, P. Walczysko, A.B. Holt, D.J. Henderson, J.D. West, A.M. Rajnicek, J.M. Collinson. The core planar cell polarity gene, Vangl2, directs adult corneal epithelial cell alignment and migration. R Soc Open Sci 3 (2016).

[42] H. Chen, D.D. Mruk, W.M. Lee, C.Y. Cheng. Planar Cell Polarity (PCP) Protein Vangl2 Regulates Ectoplasmic Specialization Dynamics via Its Effects on Actin Microfilaments in the Testes of Male Rats. Endocrinology 157 (2016) 2140-2159.

[43] J. Yuana, J. Chaa, W. Denga, A. Bartosa, X. Suna, H.-Y. H. Hob, J.-P. Borg, T.P. Yamaguchie, Y. Yangf, S.K. Dey. Planar cell polarity signaling in the uterus directs 
appropriate positioning of the crypt for embryo implantation. Proc Natl Acad Sci U S A. 113 (2016) 8079-8088.

[44] J.B. Wallingford. Planar cell polarity signaling, cilia and polarized ciliary beating. Curr. Opin. Cell Biol. 22 (2010) 597-604)

[45] B. Guirao, A. Meunier, S. Mortaud, A. Aguilar, J.M. Corsi, L. Strehl, Y. Hirota, A. Desoeuvre, C. Boutin, Y.G. Han, Z. Mirzadeh, H. Cremer, M. Montcouquiol, K. Sawamoto, N. Spassky. Coupling between hydrodynamic forces and planar cell polarity orients mammalian motile cilia. Nat Cell Biol 12 (2010) 341-3150.

[46] J. Merte, D. Jensen, K. Wright, S. Sarsfield, Y. Wang, R. Schekman \& D.D. Ginty. Sec24b selectively sorts Vangl2 to regulate planar cell polarity during neural tube closure. Nat Cell Biol 12 (2010) 41-46.

[47] Wansleeben C1, Feitsma H, Montcouquiol M, Kroon C, Cuppen E, Meijlink F. Planar cell polarity defects and defective Vangl2 trafficking in mutants for the COPII gene Sec24b. Development (2010) 137 1067-1073.

[48] J.G. D'Arcangelo, K.R. Stahmer, E.A. Miller. Vesicle-mediated export from the ER: COPII coat function and regulation. Biochim et Biophys Acta 1833 (2013) 2464-2472.

[49] X.Y. Yang, X.Y Zhou, Q.Q. Wang, H. Li, Y. Chen, Y.P. Lei, X.W Ma, P. Kong, Y. Shi, L. Jin, T. Zhang, H.Y. Wang. Mutations in the COPII vesicle component gene SEC24B are associated with human neural tube defects. Hum Mutat. 34 (2013) 1094-1101.

[50] J.M. Carvajal-Gonzalez, S. Balmer, M. Mendoza, A. Dussert, G. Collu, A.-C. Roman, U. Weber, B. Ciruna, M. Mlodzik. The clathrin adaptor AP-1 complex and Arf1 regulate planar cell polarity in vivo. Nat Commun 7 (2015) 6751.

[51] H. Strutt, S.J. Warrington, D. Strutt.Dynamics of core planar polarity protein turnover and stable assembly into discrete membrane subdomains. Dev Cell 20 (2011) 511-525.

[52] D. Shi, F. Usami, K. Komatsu, S. Oka, T. Abe, T. Uemura, T. Fujimori. Dynamics of planar cell polarity protein Vangl2 in the mouse oviduct epithelium. Mech Dev 141 (2016) 78-89.

[53] I. Roszko, Diane S. Sepich, Jason R. Jessen, Anand Chandrasekhar, Lilianna SolnicaKrezel. A dynamic intracellular distribution of Vangl2 accompanies cell polarization during zebrafish gastrulation. Development 142 (2015) 2508-2520.

[54] O. Ossipova, K. Kyeongmi, S.Y. Sokol. Planar polarization of Vang12 in the vertebrate neural plate is controlled by Wnt and Myosin II signaling. Biology Open 4 (2015) 722-730.

[55] T. Nagaoka, A. Inutsuka, K. Begum, K.M. Bin Hafiz, M. Kishi. Vang12 Regulates ECadherin in Epithelial Cells. Sci Rep. 4 (2014) 6940.

[56] A.P. Giese, J. Ezan, L. Wang, L. Lasvaux, F. Lembo, C. Mazzocco, E. Richard, J. Reboul, J.P. Borg, M.W. Kelley, N. Sans, J. Brigande, M. Montcouquiol, Gipc1 has a dual role in Vang12 trafficking and hair bundle integrity in the inner ear. Development 139 (2012) $3775-3785$. 
[57] E. Belotti, J. Polanowska, A.M. Daulat, S. Audebert, V. Thome, J.C. Lissitzky, F. Lembo, K. Blibek, S. Omi, N. Lenfant, A. Gangar, M. Montcouquiol, M.J. Santoni, M. Sebbagh, M. Aurrand-Lions, S. Angers, L. Kodjabachian, J. Reboul, J.P. Borg, The human PDZome: a gateway to PSD95-Disc large-zonula occludens (PDZ)-mediated functions. Mol Cell Proteomics 12 (2013) 2587-2603.

[58] F. Steinberg, M. Gallon, M. Winfield, E.C. Thomas, A.J. Bell, K.J. Heesom, J.M. Tavaré P.J. Cullen. A global analysis of SNX27-retromer assembly and cargo specificity reveals a function in glucose and metal ion transport. Nat Cell Biol 15 (2013) 461-471.

[59] S. Li, R. Esterberg, V. Lachance, D. Ren, K. Radde-Gallwitz, F. Chi, J.L. Parent, A. Fritz, P. Chen, Rack1 is required for Vangl2 membrane localization and planar cell polarity signaling while attenuating canonical Wnt activity. Proc Natl Acad Sci U S A 108 (2011) 2264-2269

[60] N. Escobedo, O. Contreras, R. Muñoz, M. Farías, H. Carrasco, C. Hill, U. Tran, S.E. Pryor, O. Wessely, A.J. Copp, J. Larraín. Syndecan 4 interacts genetically with Vangl2 to regulate neural tube closure and planar cell polarity. Development 140 (2013) 3008-3017.

[61] Y. Wang, N. Baeyens, F. Corti, K. Tanaka, J. S. Fang, J. Zhang, Y. Jin, B. Coon, K.K. Hirschi, M.A. Schwartz, M.Simons, Syndecan 4 controls lymphatic vasculature remodeling during mouse embryonic development, Development 143 (2016) 4441-4451.

[62] L.M. Kallay, A. McNickle, P.J. Brennwald, A.L. Hubbard, L.T. Braiterman, Scribble associates with two polarity proteins, Lgl2 and Vangl2, via distinct molecular domains, J Cell Biochem 99 (2006) 647-64.

[63] T.M. Puvirajesinghe, F. Bertucci, A. Jain, P. Scerbo, E. Belotti, S. Audebert, M. Sebbagh, M. Lopez, A. Brech, P. Finetti, E. Charafe-Jauffret, M. Chaffanet, R. Castellano, A. Restouin, S. Marchetto, Y. Collette, A. Goncalves, I. Macara, D. Birnbaum, L. Kodjabachian, T. Johansen, J.P. Borg, Identification of p62/SQSTM1 as a component of non-canonical Wnt VANGL2-JNK signalling in breast cancer, Nat Commun 7 (2016) 10318.

[64] T. Young, Y. Poobalan, E.K. Tan, S. Tao, S. Ong, P. Wehner, J. Schwenty-Lara, C.Y. Lim, A. Sadasivam, M. Lovatt, S.T. Wang, Y. Ali, A. Borchers, K. Sampath, N.R. Dunn, The PDZ domain protein Mcc is a novel effector of non-canonical Wnt signaling during convergence and extension in zebrafish, Development 141 (2014) 3505-3516.

[65] J.H. Wald, J. Hatakeyama, I. Printsev, A. Cuevas, W.H.D. Fry, M.J. Saldana, K. VanderVorst, A. Rowson-Hodel, J.M. Angelastro, C. Sweeney, K.L. Carraway Rd, Suppression of planar cell polarity signaling and migration in glioblastoma by Nrdp1mediated Dvl polyubiquitination, Oncogene (2017).

[66] M. Park, R.T. Moon. The planar cell-polarity gene stbm regulates cell behaviour and cell fate in vertebrate embryos. Nat Cell Biol 4 (2002) 20-25.

[67] A.M. Daulat, O. Luu, A. Sing, L. Zhang, J.L. Wrana, H. McNeill, R. Winklbauer, S. Angers. Mink1 Regulates $\beta$-Catenin-Independent Wnt Signaling via Prickle Phosphorylation. Mol Cell Biol 32 (2012) 173-185.

[68] H. Yin, C.O. Copley, L.V. Goodrich, M.R. Deans. Comparison of phenotypes between different vang12 mutants demonstrates dominant effects of the Looptail mutation during hair cell development, PLoS One. 7(2) (2012) e31988. 
[69] H. Strutt, J. Gamage, D. Strutt. Robust asymmetric localization of planar polarity proteins is associated with organization into signalosome-like domains of variable stoichiometry. Cell Rep 17 (2016) 2660-2671.

[70] J.-R. Courbard, A. Djiane, J. Wu, M. Mlodzik. The apical/basal-polarity determinant Scribble cooperates with the PCP core factor Stbm/Vang and functions as one of its effectors, Dev Biol 333 (2009) 67-77.

[71] F. Kharfallah, M.C. Guyot, A.R. El Hassan, R. Allache, E. Merello, P. De Marco, G. Di Cristo, V. Capra, Z. Kibar. Scribble1 plays an important role in the pathogenesis of neural tube defects through its mediating effect of Par-3 and Vangl1/2 localization, Hum Mol Genet 26 (2017) 2307-2320.

[72] R. Yao, Y. Natsume, T. Noda, MAGI-3 is involved in the regulation of the JNK signaling pathway as a scaffold protein for frizzled and Ltap, Oncogene 23(36) (2004) 60236030 .

[73] O.K. Lee, K.K. Frese, J.S. James, D. Chadda, Z.H. Chen, R.T. Javier, K.O. Cho, DiscsLarge and Strabismus are functionally linked to plasma membrane formation. Nat Cell Biol 5 (2003) 987-993.

[74] T. Yoshioka, A. Hagiwara, Y. Hida, T. Ohtsuka, Vang12, the planar cell polarity protein, is complexed with postsynaptic density protein PSD-95. FEBS Lett 587 (2013) 1453-1459.

[75] T. Nagaoka, K. Tabuchi, M. Kishi. PDZ interaction of Vangl2 links PSD-95 and Prickle2 but plays only a limited role in the synaptic localisation of Vangl2, Sci Rep 5 (2015) 12916.

[76] P. Andre, Q. Wang, N. Wang, B. Gao, A. Schilit, M.M. Halford, S.A. Stacker, X. Zhang, Y. Yang, The Wnt coreceptor Ryk regulates Wnt/planar cell polarity by modulating the degradation of the core planar cell polarity component Vang12. J Biol Chem 287 (2012) 44518-44525.

[77] R. Suriben, S. Kivimae, D.A. Fisher, R.T. Moon, B.N. Cheyette, Posterior malformations in Dact1 mutant mice arise through misregulated Vang12 at the primitive streak, Nat Genet 41(9) (2009) 977-985.

[78] X.Y. Yang, B.N. Cheyette. SEC14 and spectrin domains 1 (Sestd1) and Dapper antagonist of catenin 1 (Dact1) scaffold proteins cooperatively regulate the Van Gogh-like 2 (Vang12) four-pass transmembrane protein and planar cell polarity (PCP) pathway during embryonic development in mice. J Biol Chem. 288 (2013) 20111-20120.

[79] M. Lindqvist, Z. Horn, V. Bryja, G. Schulte, P. Papachristou, R. Ajima, C. Dyberg, E. Arenas, T.P. Yamaguchi, H. Lagercrantz, T. Ringstedt, Vang-like protein 2 and Rac1 interact to regulate adherens junctions, J Cell Sci 123 (2010) 472-483.

[80] B. Shafer, K. Onishi, C. Lo, G. Colakoglu, Y. Zou. Vangl2 Promotes Wnt/Planar Cell Polarity-like Signaling by Antagonizing Dvl1-Mediated Feedback Inhibition in Growth Cone Guidance, Dev Cell. 20 (2011) 177-191.

[81] T. Nagaoka, R. Ohash, A. Inutsuka, S. Sakai, N. Fujisawa, M. Yokoyama, Y.H. Huang, M. Igarashi, M. Kishi. The Wnt/planar cell polarity pathway component Vang12 induces synapse formation through direct control of N-cadherin, Cell Rep. 6 (2014) 916-927. 
[82] S. Babayeva, B. Rocque, L. Aoudjit, Y. Zilber, J. Li, C. Baldwin, H. Kawachi, T. Takano, E. Torban. Planar cell polarity pathway regulates nephrin endocytosis in developing podocytes. J Biol Chem 288 (2013) 24035-24048.

[83] B.B. Williams, V.A. Cantrell, N.A. Mundell, A.C. Bennett, R.E. Quick, J.R. Jessen. VANGL2 regulates membrane trafficking of MMP14 to control cell polarity and migration. J Cell Sci. 125 (2012) 2141-2147.

[84] E. Torban, A. Iliescu, P. Gros. An expanding role of Vangl proteins in embryonic development, Curr Top Dev Biol 101 (2012) 237-261.

[85] M. Sebbagh, J.-P. Borg. Insight into planar cell polarity. Exp Cell Res 328 (2014) 284295.

[86] E.K.Vladar, J.V. Nayak, C.E. Milla, J.D. Axelrod. Airway epithelial homeostasis and planar cell polarity signaling depend on multiciliated cell differentiation. JCI Insight. 1 (2016). pii: e88027

[87] J. Hatakeyama, J.H. Wald, I. Printsev, H.-Y. Henry Ho, K.L. Carraway. Vangl1 and Vang12: planar cell polarity components with a developing role in cancer. Endocr Relat Cancer. 21 (2014) R345-R356.

[88] J.N. Anastas, T.L. Biechele, M. Robitaille, J. Muster, K.H. Allison, S. Angers, R.T. Moon. A protein complex of SCRIB, NOS1AP and VANGL1 regulates cell polarity and migration, and is associated with breast cancer progression. Oncogene 31 (2012) 3696-3708.

[89] H.L. May-Simera, R.S. Petralia, M. Montcouquiol, Y.X. Wang, K.B. Szarama, Y. Liu, W. Lin, M.R. Deans, G.J. Pazour, M.W. Kelley, Ciliary proteins Bbs8 and Ift20 promote planar cell polarity in the cochlea, Development 142 (3) (2015) 555-66. 
Figure 1. Structural and topological organization of Vangl2. (a) Schematics depicting the structural organization of Vang12 with the positions of its main domains such as the four transmembrane (TM) domains (dark blue), two Ser/Thr phosphorylation site clusters (grey), the Dvl/Pk interacting region (cyan), the C-terminal PDZ binding Motif (PBM) domains (red) or the TGN sorting motif (grey box in the C-terminal region). Positions of the two Lp mutations are also indicated by arrows. (b) Schematic representation of Vangl2 topology.

Some of the many protein interactions that Vangl2 and possibly Vangl1 as well can make, notably with the other core PCP components and the trafficking regulatory protein SNX27. Note that Scribble has been shown to interact with both Vangl1 and Vangl2.

Figure 2. Asymmetric distribution and antagonistic relationships of core PCP proteins in Drosophila wing epithelial cells. (a) Schematic representation of the asymmetric distribution of the fruit fly core PCP proteins in the wing epithelium. The distal positioning and tilting of each trichome is also depicted in each cell. The proximally accumulated Vang/Stbm-Pk complex is in red while the distally enriched Fr-Dsh complex is shown in green. (b) Schematics depicting the positive (double black arrows) intercellular interactions and the antagonizing intracellular interactions between opposing complexes formed by Vang/Stbm-Pk on the proximal pole and by Fz/Dsh on the distal edge of the cells.

Figure 3. A model of paralog-specific protein interactions and complex composition. In this model, we speculate on the possible functional consequences of having Vangl1 (green pies) and Vang12 (red pies) complexes of various composition, stoichiometry and paralog specific interactors. We arbitrarily opted for a scenario whereby Vangl1 and Vangl2 make hexamers based on previous report [69]. In this model and depending on which isoform is expressed in a given cell type, Vangl1 and Vangl2 can form homohexamers (a) and (b) or heterohexamers (c), (d) and (e). To further elaborate on this scenario, we postulate that Scribble (black triangles) can interact with both isoforms while p62/SQSTM1 (blue triangles) has a Vang12-specific interaction associated with proliferative and pro-migratory properties. Finally we assume that the subunit ratio between Vangl1 and Vangl2 in the complexes reflects the relative concentration of each paralog. 
Figure 4. Model of epithelial cell transformation with concomitant upregulation of Vang12. Here we further elaborate at the tissular level on the molecular model presented in Figure 2. Our model depicts the consequences of a Vangl2 up-regulation following an oncogenic event in an epithelium that originally expresses both isoforms and in which Scribble-dependent apical-basal and PCP signaling are strongly disrupted by a sudden excess of Vang12. This model is largely inspired based on our recently published data [63]. 
a)

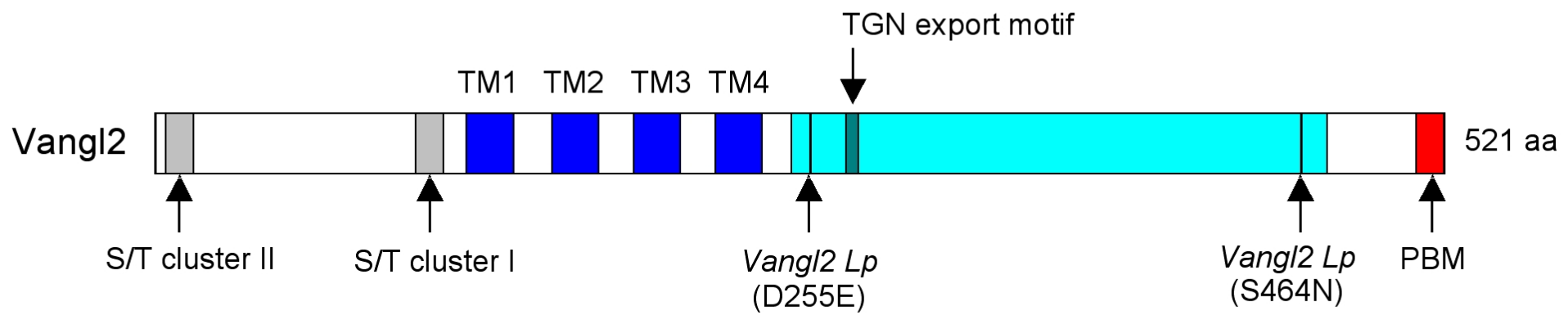

b)

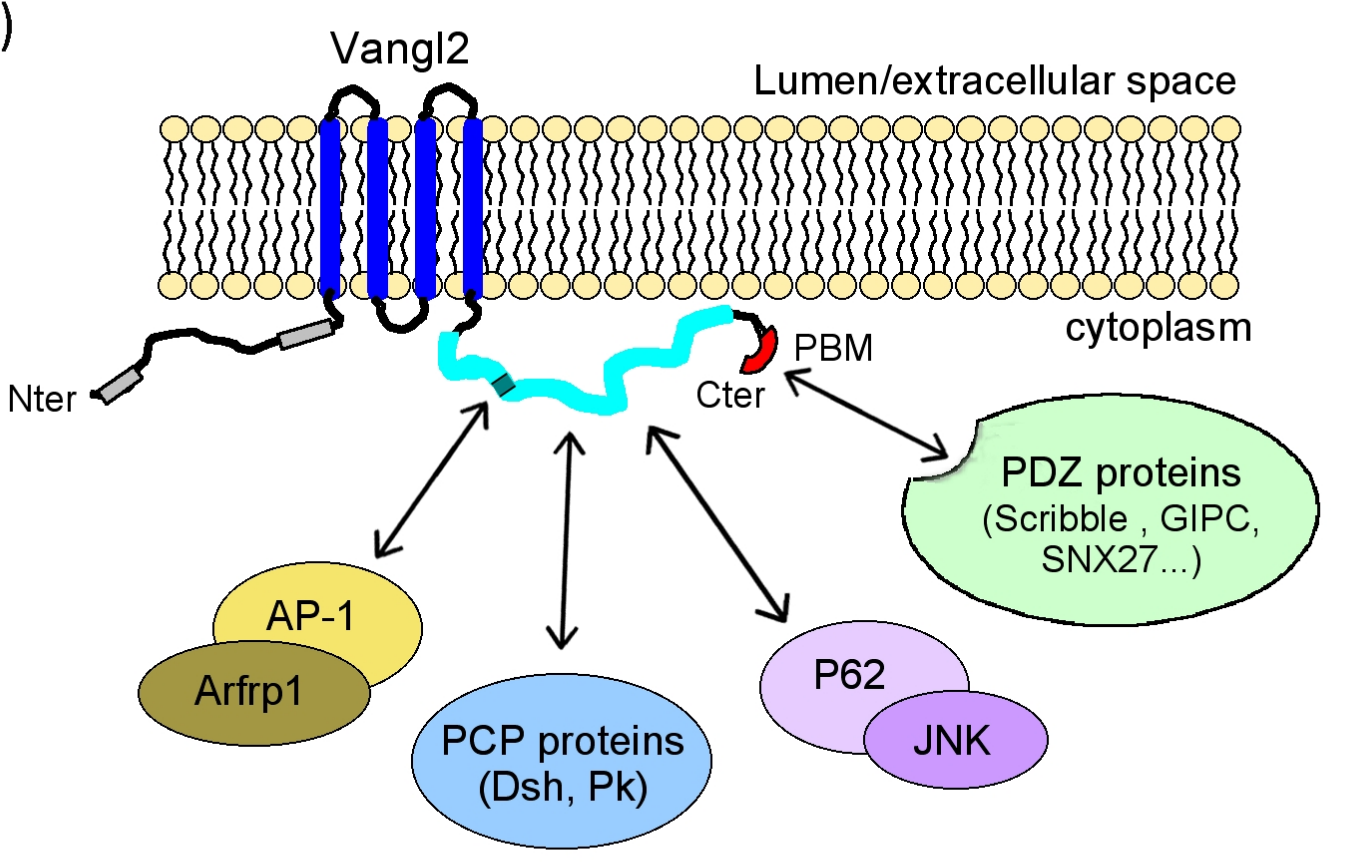

Bailly et al. Figure 1 
a)

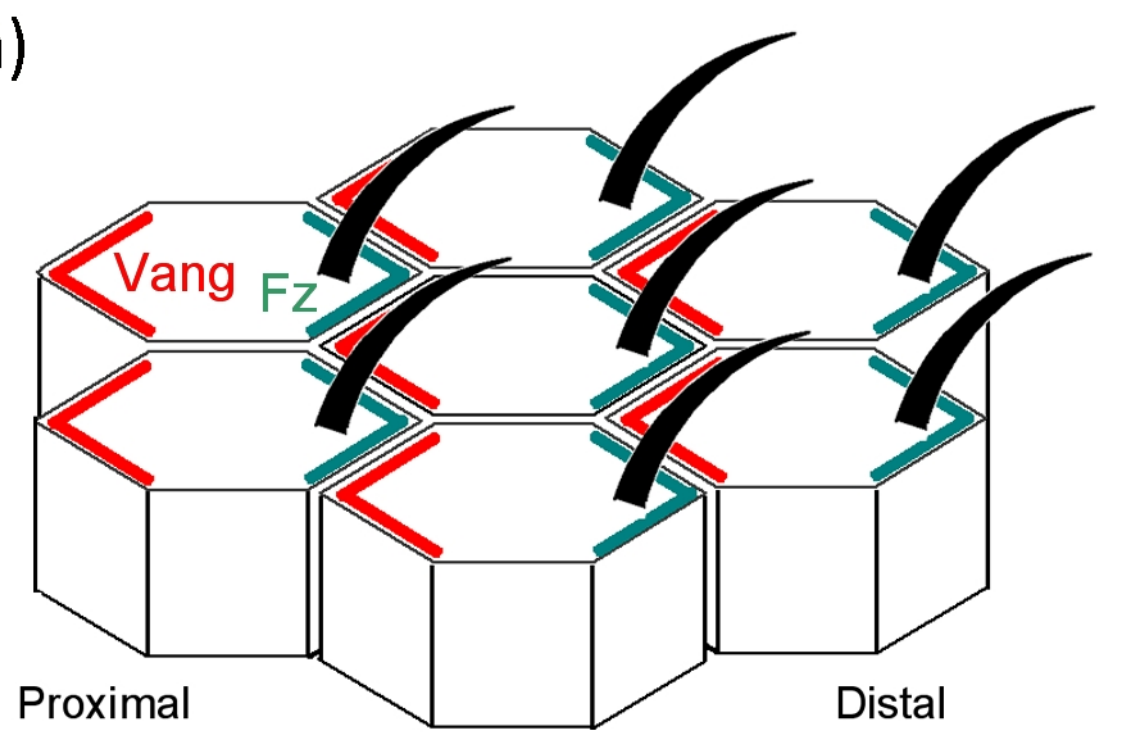

b)

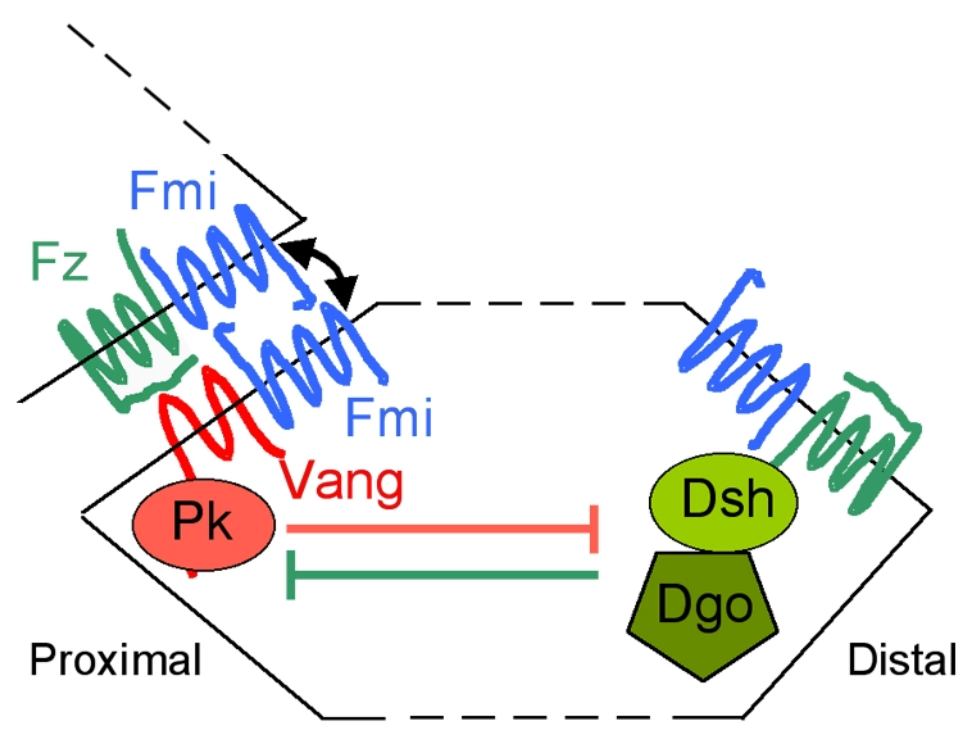

\section{Bailly et al. Figure 2}




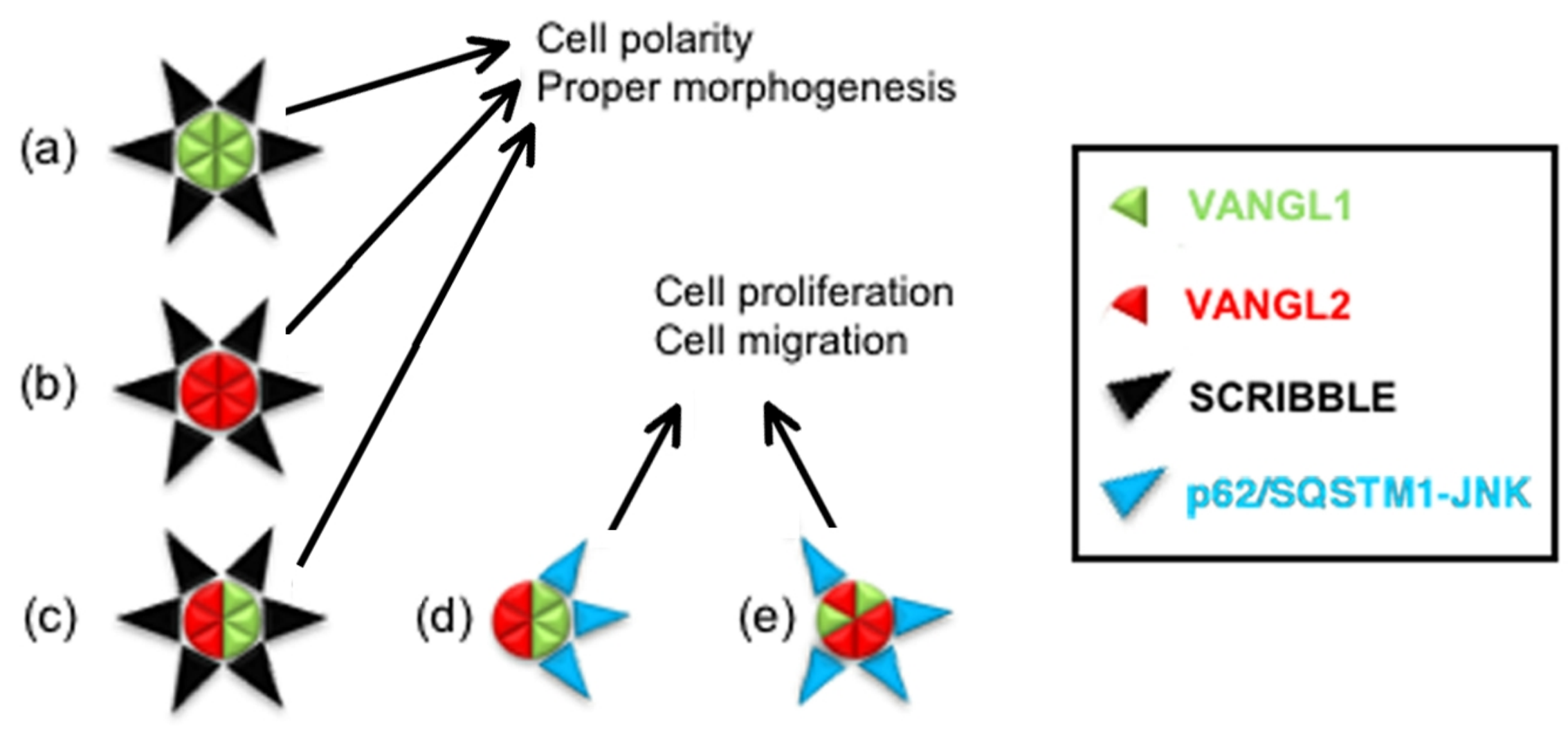

Bailly et al. Figure 3 

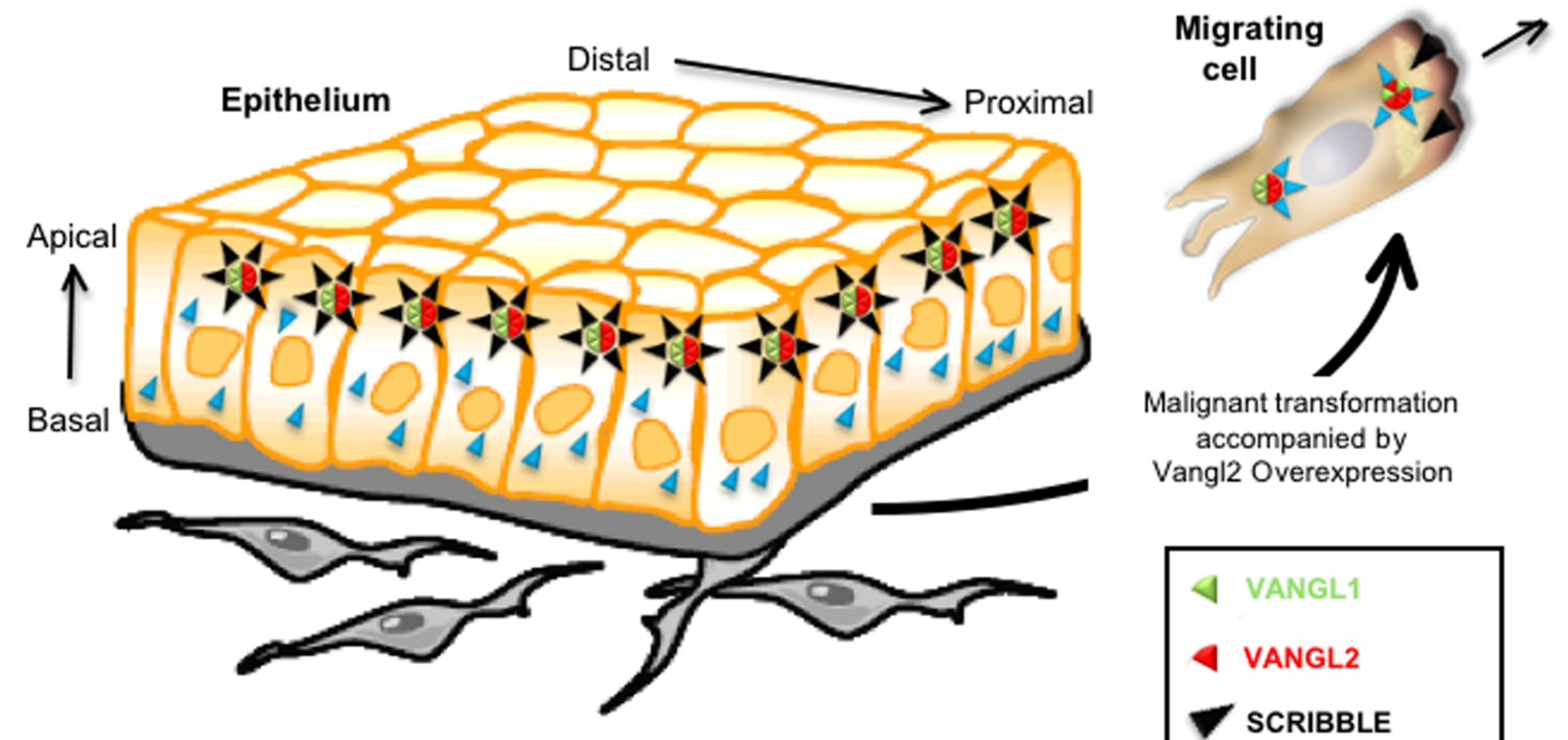

Malignant transformation accompanied by

Vangl2 Overexpression

\begin{tabular}{|l|}
\hline VANGL1 \\
VANGL2 \\
SCRIBBLE \\
p62/SQSTM1-JNK
\end{tabular}

Bailly et al. Figure 4 